\title{
Long Term Monitoring of Rosa arabica Populations as a Threatened Species in South Sinai, Egypt
}

\author{
Moustafa AA ${ }^{1 *}$, Zaghloul MS ${ }^{1}$, Mansour SR ${ }^{1}$, Alsharkawy $\mathbf{D H}^{1}$ and Alotaibi $\mathbf{M}^{2}$ \\ ${ }^{1}$ Botany Department, Faculty of Science, Suez Canal University, 41522 Ismailia, Egypt \\ ${ }^{2}$ Department of Biology, Faculty of Science - Princess Nora University Kingdom of Saudi Arabia
}

\begin{abstract}
Rosa arabica is a threatened species of the family Rosaceae, endemic to Mount Catherine region in the South Sinai, Egypt. The aim of this study was to evaluate the status of the $R$. arabica populations after a conservation program that has been started eighteen years ago. Fencing of the target species was applied in three main locations in Saint Katherine protectorate; Kahf El-Ghola, Wadi El-Arbaen and Shaq Mussa. Soil analysis and seed bank content were assessed for the three localities. Evaluation of the obtained results showed that $R$. arabica has negatively reacted to the fencing in enclosures of Kahf El-Ghola and Shaq Mussa, while the enclosure in Wadi El-Arbaen showed a significant increase in plant growth and cover. The soil seed bank of Rosa arabica reflected a reluctant of seed germination and no emergence of Rosa seedlings were observed, however, other important species (including endemic sp.) which was not in the standing vegetation were recorded. Thymus decussatus, Capparis sinaica, Mentha longifolia, Peganum harmala, Pulicaria crispa, Teucrium polium, and Verbascum sinaiticum, are examples of the emerged species out of the soil seed bank.
\end{abstract}

Keywords: Conservation; Population ecology; Endemic species; Sinai; Rosaceae

\section{Introduction}

South Sinai, arid to extremely arid region, characterized by an ecological uniqueness, due to its diversity in landforms, geologic structures, and climate. This resulted in diversity in vegetation types, which is characterized mainly by; 1) sparseness and dominance of shrubs and sub-shrubs, 2) paucity of trees [1], and 3) variation in soil properties [2-4]. The mountainous area of south Sinai harbors 26 endemic species [5]. Of the species were recorded in Saint Katherine Protectorate, 10 are extremely endangered, 53 are endangered, and 37 species are vulnerable. Nearly half of the endemic species found in Saint Katherine Protectorate are vulnerable, rare, endangered, or extremely endangered [5] and subjected to great disturbance due to the severe impact of the human activities. Species were classified as rare, vulnerable, endangered and extremely endangered based on the local distribution within the protectorate's boundaries and human impact and according to the IUCN [6] definitions of threatened species. The continuous overgrazing, over-collection (cutting and uprooting for fuel and medicinal uses), tourism and urbanization resulted in disappearance of pastoral plants, paucity of trees and shrubs as well as disappearance of many rare and endemic species [5].

In 2004, Abd El-Wahab et al. surveyed the medicinal plants in Saint Catherine Protectorate's mountains and wadis recording a list of 128 species belonging to 43 taxonomic families. Labiatae was the most represented family followed by Compositae and Leguminosae. Rosaceae was represented only by three species; Cotoneaster orbicularis, Crataegusx sinaica and Rosa arabica.

Rose family comprises about 90 genera with 2500 species distributed worldwide. Most of the Rosa family members are used for commercial cut flower crops and commercial perfumery. Some of the roses are used as landscape plants, for hedging and for other utilitarian purposes such as game cover and slope stabilization while they also have medicinal uses $[7,8]$. Flowers, petals, and fruits of Roses are used for medical purpose. In ancient medical books, several therapeutic effects of these plants had been recorded such as; strengthening the heart, treatment of abdominal and chest pain, treatment of digestive problems, menstrual bleeding, and anti-inflammation [9]. A decoction of the root of Rosa damascena plant is used as a cough remedy to ease children's cough [10].

Rosa arabica is a perennial shrub with stems up to three meters long, belongs to family Rosaceae that is represented in South Sinai by seven species. Its leaflets are obovate, strongly double-serrate, little glands are found on the upper surface and glabrous. It blooms in late spring and disperse its seeds in late summer [11-13]. It grows in mountainous wadis and gorges with rocky ground $(40 \%)$ and northwest-facing (20\%) and steep granite slopes of up to $90^{\circ}$ on west [1]. R. arabica is an endemic medicinal species which grows in a very restricted specific type of habitat and is represented by a few numbers of populations. It is collected severely and uprooted and subsequently became rare or even threatened as it is characterized by having a high medicinal uses due to its active constituents [5]. The aqueous ethanolic whole plant extract was found to contain the natural dimeric phenolic compound, ellagic acid 3, 3'-dimethyl ether 4-0-a-rhamnopyranoside, 9, along with ten known phenolic metabolites [14].

Our main objective in the present study is the evaluation of the botanical conservation status of the endemic, threatened, and rare species Rosa arabica in Saint Catherine area, and consequently the associated species found with Rosa, in the fenced studied localities, which was monitored in a project started in summer 1998.

*Corresponding author: Moustafa AA, Botany Department, Faculty of Science Suez Canal University, 41522 Ismailia, Egypt, Tel: 00201211182111; E-mail: raoufmoustafa2@hotmail.com

Received August 28, 2017; Accepted September 12, 2017; Published September 14, 2017

Citation: Moustafa AA, Zaghloul MS, Mansour SR, Alsharkawy DH, Alotaibi M (2017) Long Term Monitoring of Rosa arabica Populations as a Threatened Species in South Sinai, Egypt. J Biodivers Endanger Species 5: 197. doi: 10.4172/23322543.1000197

Copyright: ( 2017 Moustafa AA, et al. This is an open-access article distributed under the terms of the Creative Commons Attribution License, which permits unrestricted use, distribution, and reproduction in any medium, provided the original author and source are credited. 


\section{Materials and Methods}

\section{Study area}

Saint Katherine Protectorate, the area of the study is located between $33^{\circ} 30^{\prime}$ and $34^{\circ} 30^{\prime} \mathrm{E}$ and $27^{\circ} 50^{\prime}$ and $28^{\circ} 50^{\prime} \mathrm{N}$ and covers about $4350 \mathrm{~km}^{2}$ with elevation ranges from 396 to $2642 \mathrm{~m}$. It is characterized by diversity in landforms, geological structures, and climate. These unique features led to the existence of several microhabitats, each of them has its peculiar ecological conditions that reflect a relatively rich and unique flora [1]. The study area includes: Wadi El-Arbaen and Shaq Mussa (Figure 1).

Geomorphologically, Saint Catherine area is formed of highly rugged mountains with acid plutonic and volcanic rocks-belonging to the Precambrian basement complex of the southern part of Sinai Peninsula which is dissected by numerous incised Wadis that are everywhere showing signs of down cutting [15]. Wadi El-Arbaen subbasin area is considered one of the important areas of Wadi Ghreaba basin in the central part of South Sinai. It is deep, narrow, and roughly filled by huge boulders and is bounded approximately by latitudes $28^{\circ} 53^{\prime}$ to $28^{\circ} 55^{\prime}$ north and longitudes $33^{\circ} 94^{\prime}$ to $33^{\circ} 95^{\prime}$ east. The average width of the Wadi bed is around $50 \mathrm{~m}$, the bed rocks are mostly granitic. The elevation of the studied stands ranges from 1580 to 1660 $\mathrm{m}$ a. s. While, Shaq-Mussa sub-basin area is bounded approximately by latitudes $28^{\circ} 52^{\prime}$ to $28^{\circ} 53^{\prime}$ north and longitudes $33^{\circ} 56^{\prime}$ to $33^{\circ} 57^{\prime}$ east. The rock unit of Shag-Mousa area is volcanic; it is very narrow and roughly filled by huge boulders. The width of this Wadi along area varies from 6 to $50 \mathrm{~m}$, the studied stands height above sea level of ranges from 1690 to $1760 \mathrm{~m}$ a.s.l.

Saint Catherine is the coolest area in Sinai and Egypt due to its high elevation [16]. The lowest minimum temperature was recorded in January and February $\left(-3^{\circ} \mathrm{C}\right.$ and $\left.-6^{\circ} \mathrm{C}\right)$, while the highest maximum temperature was in June and August $\left(42^{\circ} \mathrm{C}\right.$ and $43^{\circ} \mathrm{C}$, respectively). Figure 2 records the change in the annual precipitation during the period of 1970 to 2017 obtained from Saint Catherine International Airport station where the years 2012, 2013 and 2014 showed the highest record of annual precipitation ever happened in the whole history of Sinai [17]. In fact, that record of highest annual rain rises up the question of climate change in the area and certainly needs lots of future studies to emphasize the reality of these remarks. The recorded data showed that the winter seasons of 2012/2013 and 2013/2014 ) (Figure 3) were unusual in the rate of precipitation; rain and snow in which two snow storms were recorded during December $11^{\text {th }}, 12^{\text {th }}$ and on February $19^{\text {th }}$.

\section{Methods}

Species conservation in situ (fencing): Three permanent enclosures had been established, against grazing and human interference, to protect and monitor Rosa arabica species. The fencing area was established at middle to late summer in 1998 and constructed in a manner to be permanent for long-term monitoring. The selection of these fenced plots was based on the abundance of threatened Rosa arabica populations as a basic requirement. The size and the site selection of a given stand depended on its accessibility, the presence of natural features supportive of the adopted protection scheme, and on having a realistic degree of physiognomic homogeneity in its topography and vegetation type.

Phytosociological parameters were measured and expressed as vitality and total plant cover percentage. Vitality is concerned with the normal growth and reproductive ability of the species which helps it in maintaining position in the community. Based on the vitality scales [1820], a modified scale was applied in which $\mathrm{V}_{1}=$ bad shaped plant species, $\mathrm{V}_{2}=$ poor growth plant species, $\mathrm{V}_{3}=$ plant species have reasonable vegetative growth, $\mathrm{V}_{4}=$ plant species in the flowering state, $\mathrm{V}_{5}=$ fruiting and seed shedding plant species. The total cover percentage, of each plant species, was calculated in all enclosures.

In each locality, the following parameters were measured: altitude (msl), slope degree, exposure degree, and landform type. Landform type was determined according to Moustafa and Klopatek [1] as gorge, slope,

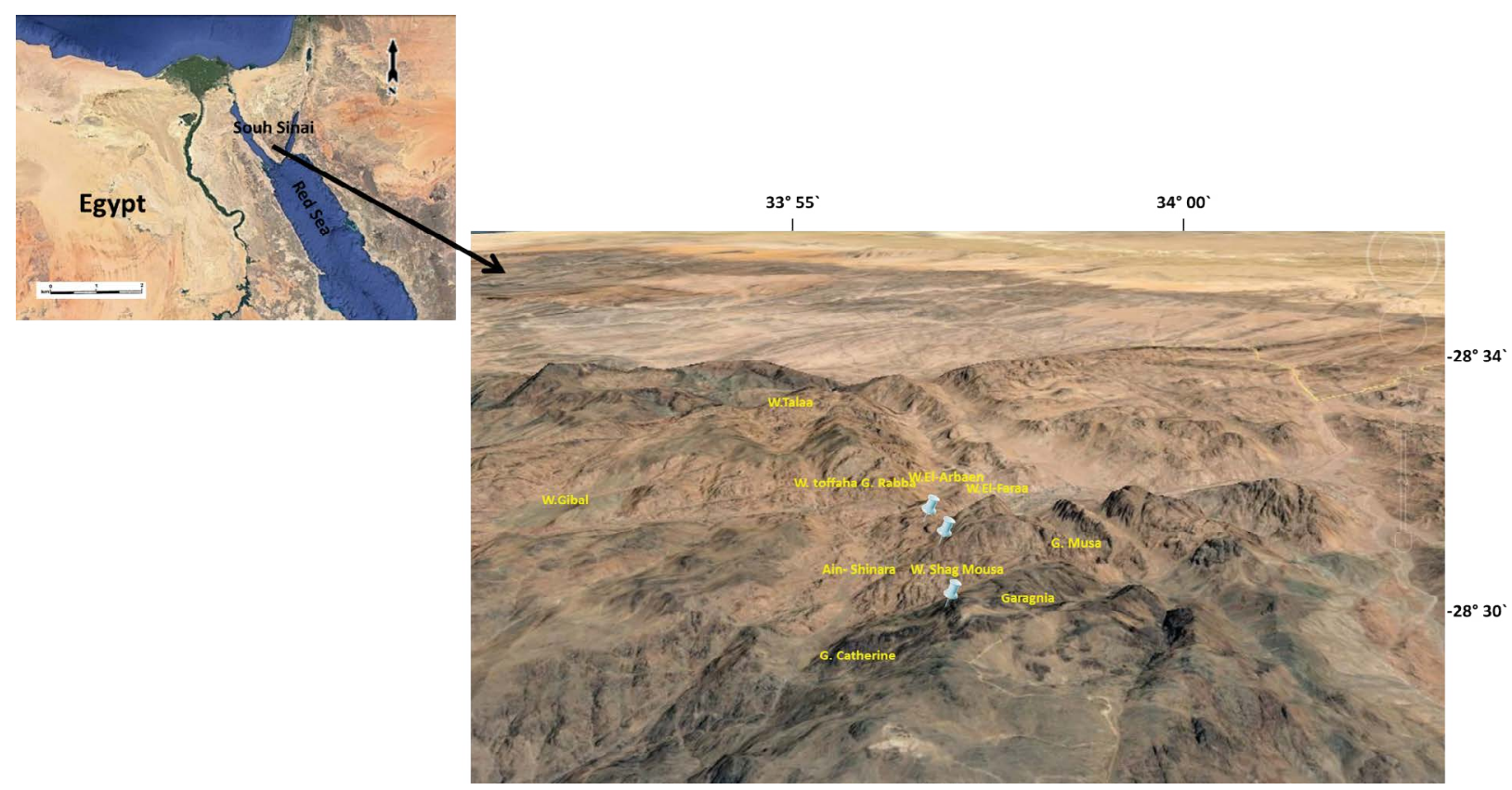

Figure 1: Satellite image of Saint Catherine area, showing the locations of the three enclosures of Rosa arabica in Kahf El- Ghola, Wadi El-Arbae'en and Shaq Mussa. 
Citation: Moustafa AA, Zaghloul MS, Mansour SR, Alsharkawy DH, Alotaibi M (2017) Long Term Monitoring of Rosa arabica Populations as a Threatened Species in South Sinai, Egypt. J Biodivers Endanger Species 5: 197. doi: 10.4172/2332-2543.1000197

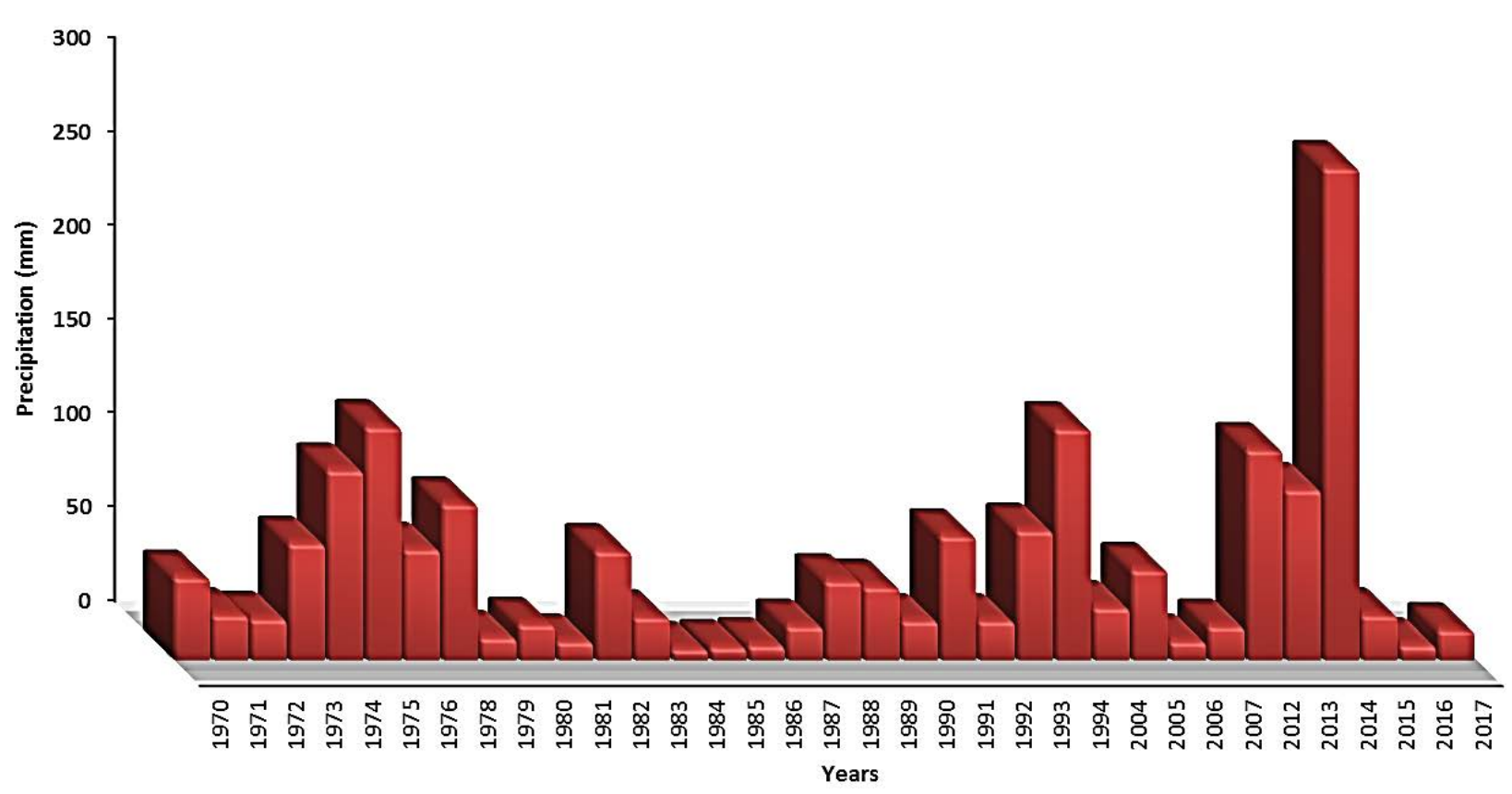

Figure 2: Annual precipitation (mm) in Saint Catherine area during the period of 1970-2017.

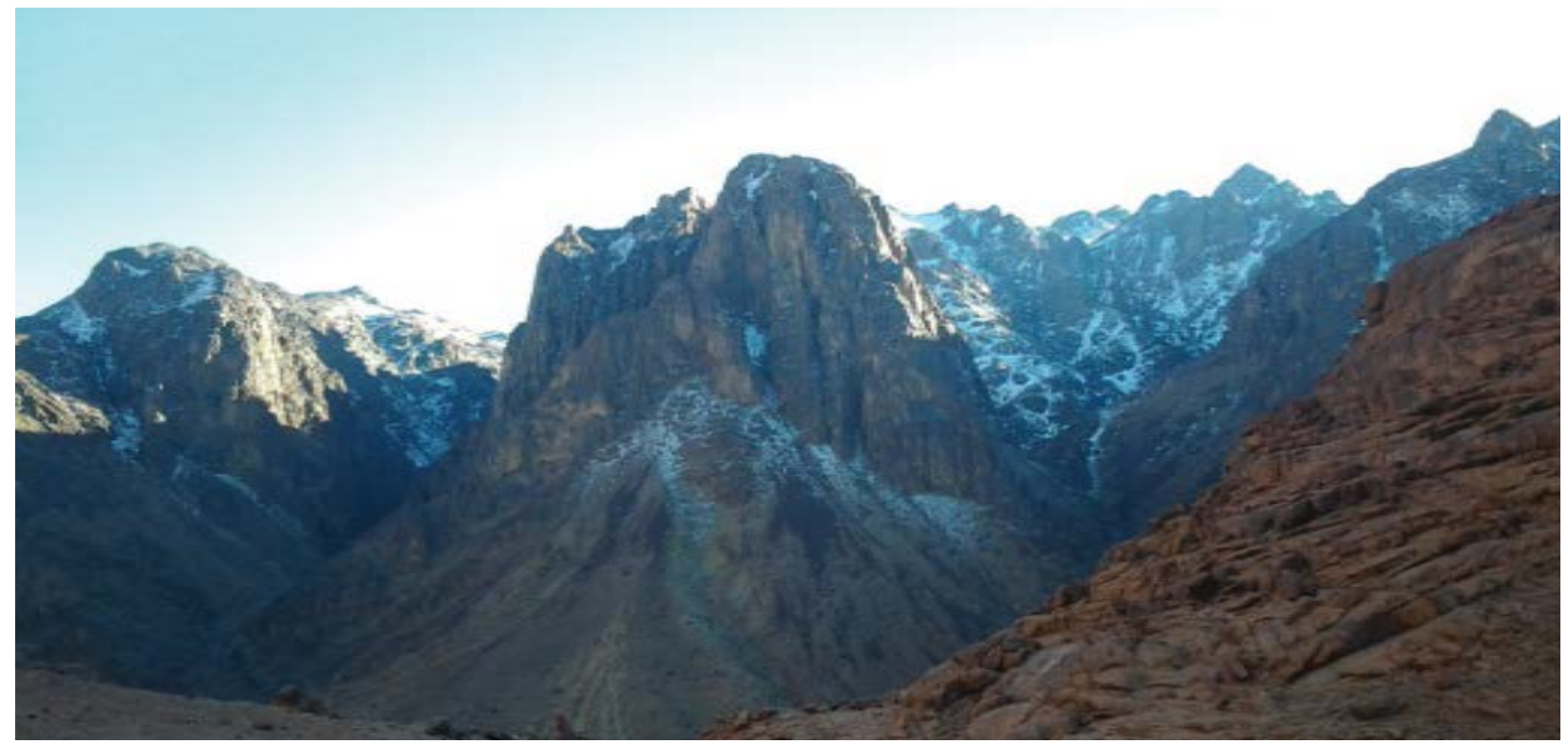

Figure 3: Snow fall on mountain Catharine, February 2013.

wadi, terraces, caves and outcrop of smooth-faced rock. Nature of soil surface was described using the following scale; fine fraction $(<2 \mathrm{~mm})$, gravel $(2-75 \mathrm{~mm})$, cobbles $(75-250 \mathrm{~mm})$, stones $(250-600 \mathrm{~mm})$, and boulders $(>600 \mathrm{~mm})$ [21]. Soil samples were collected for quantitative physical analysis as well as $\mathrm{pH}$ and $\mathrm{EC}$ measurements.

\section{Soil analyses}

Physical analysis: The collected soil samples were air dried and manually sieved through a $2 \mathrm{~mm}$ sieve to evaluate gravel percent. Soil moisture content was measured immediately after soil sampling using gravimetric method. Distribution of soil particle-size was also analyzed following the method of Gee and Bauder [22] in which sieving method was applied. The organic matter content of soil samples was determined by weight loss on ignition, following the method of Sparks et al. [23].

Chemical analysis: The $\mathrm{pH}$ values of soil samples were measured using digital pH meter (Hanna, HI991300). The soil extract was done in ratio of 2.5:1 soil to distilled water following Allen et al. [24]. However, electric conductivity (EC) was measured for the same soil extract according to Wilde et al. [25]. 


\section{Soil seed bank}

The most direct method for detecting the presence of viable seeds in soil is to observe the emergence of seedlings in situ [26]. The representative soil samples were taken and placed in greenhouse for seed germination. Appropriate amount of soil each sample was distributed homogenously on a surface of plate, with approximate diameter $30 \mathrm{~cm}$, filled with thin layer of acid washed-sandy soil. For each soil sample three replicas were carried out. The plates kept moist and left under greenhouse condition.

\section{Results and Discussion}

Ecological monitoring is a combination of techniques that enables data to be collected, relatively cheaply, on the life-support capacities of large areas of land. A single survey reveals only a static situation, frozen in time. Continuous monitoring over a span of time is usually much more useful, revealing changes in the ecosystem caused by conservation practices. The ecological monitoring can not only provide information to produce an action plan but can also provide feedback on the effects of the action taken.

\section{Fencing}

This present study is based on the results of the botanical survey that has been done in 1996-to 1998.The main results were that 316 species already existed in Saint Catherine protectorate and more than 200 species hard to be found due to many threats. The identified species belong to 56 families: Compositae, Graminae, Labiatae, Caryophyllaceae, Scrophulariaceae and Cruciferae are the families that represented largely the number of species respectively.

Previous results indicated that ten species were extremely endangered, fifty-three species endangered, and thirty-seven vulnerable. Therefore, they had to design a management plan for all Saint Catherine vegetation and to reinforce idea of mandatory grazing restrictions to conserve the World Heritage Sites for upcoming generations [27]. Experimental enclosures are used as management tool to exclude the effects of herbivory on recruitment in plant communities and species richness [28]. As fenced areas furnish excellent reference plots for interpreting the effect of grazing on vegetation dynamics [27]. The first priority was to construct a group of enclosures, (small sizes) around the most extremely endangered plants such as, Ballota kaiseri, Rosa arabica, and Primula boveana (Table 1).

Here are the results of conservation enclosures that were constructed for Rosa arabica species:

Enclosure No. 1: The enclosure is set in a huge cave, Kahf El-Ghoula (Figure 4) located on the right-hand side of Wadi El-Arbae'en. The cave is carved in a granite terrain and is about $175 \mathrm{~m}^{2}$ in surface area. Moisture seeping down the walls makes the ambient temperature of the cave considerably lower than usual. The cave is, therefore, characterized by the uniqueness of its floristic composition, it is distinguished by a group of rare endemic species such as Primula boveana (Primulaceae), Rosa arabica, Crataegus x Sinaica (Rosaceae), Hypricum sinaicum, Nepeta septemcrenata, and Ballota undulata (Labiatae), in addition to other rare species such as Ballota kaiseri, Ballota saxatilis, and Pterocephalus. Its location at a relatively high elevation has made frequent visits to the cave rather difficult for Bedouins and tourists. Before constructing this enclosure, the Bedouins used to spend their free time barbecuing inside the cave itself (on the expense of its unique vegetation). Because of its unique floristic composition; the enclosure is divided into three main sites. The following is a brief description of these sites:

Site 1: This site covers the gate area of the cave. It is dominated by shrubs of Rosa Arabica (Figure 5). Rosa was represented by six individuals in the first reading. They had increased their total area of crown and height by the time of the second reading its cover percentage was $11.22 \%$. In addition to this, two individuals of Crataegus $\mathrm{x}$ Sinaica appeared by the time of the second reading. In the third reading, a slight increase in the cover percentage of Rosa Arabica was also recorded $(12.75 \%)$. Here we could attribute the recovery rate of vegetation to the fencing enclosure. The increase of species number inside the enclosure showed the valuable effect of fencing on the floristic richness [29].

Site 2: This site covers a slope that ends with a shallow depression filled with a reasonable soil cover, and is therefore characterized by diversified vegetation. However, the number of species increased from

\begin{tabular}{|c|c|c|c|}
\hline Enclosure no. & 1 & 2 & 3 \\
\hline Location & Kahf El- Ghola & Garden of the Monastery at the end of Wadi El-Arbae'en & Shaq Musa \\
\hline Associated species & $\begin{array}{c}\text { Ballota kaiseri } \\
\text { Ballota saxitilis } \\
\text { Crategus x sinaica } \\
\text { Ficus palmata } \\
\text { Hypericum sinaicum } \\
\text { Jancus sp. } \\
\text { Mentha longifolia } \\
\text { Nepeta septemcrenata } \\
\text { Origanum syriacum } \\
\text { Primula boveana } \\
\text { Pterocephallus sanctus } \\
\text { Tanacetum santolinoides } \\
\text { Teucrium polium } \\
\text { Varthemia montana } \\
\text { Verbascum sinaiticum }\end{array}$ & $\begin{array}{c}\text { Achillea fragrantissima } \\
\text { Artemisa herba-alba } \\
\text { Echinops glaberrimus } \\
\text { Echinops spinossimus } \\
\text { Lectuca orientalis } \\
\text { Mathiola arabica } \\
\text { Olea europea } \\
\text { Onopordum ambiguum } \\
\text { Silene sp. }\end{array}$ & $\begin{array}{c}\text { Alkanna orientalis } \\
\text { Artemsia herba-alba } \\
\text { Ballota undulata } \\
\text { Cotoneaster orbicularis } \\
\text { Echinops glaberrimus } \\
\text { Echinops spinossimus } \\
\text { Jancus sp. } \\
\text { Nepeta septemcrenata } \\
\text { Onopordum ambiguum } \\
\text { Origanum syriacum } \\
\text { Phlomis aurea } \\
\text { Stachys aegyptiaca } \\
\text { Tanacetum santolinoides } \\
\text { Teucrium leucocaladum } \\
\text { Teucrium polium }\end{array}$ \\
\hline \multirow[b]{2}{*}{ G.P.S. record } & $\mathrm{N}: 28^{\circ} 32^{\prime} 949^{\prime \prime}$ & $\mathrm{N}: 28^{\circ} 33.0^{\prime}$ & $\mathrm{N}: 28^{\circ} 31.438^{\prime}$ \\
\hline & $\mathrm{E}: 33^{\circ} 56^{\prime} 936^{\prime \prime}$ & $\mathrm{E}: 33^{\circ} 58.1^{\prime}$ & $E: 33^{\circ} 57.587^{\prime}$ \\
\hline Elevation & $1650 \mathrm{~m}$ a.s.l. & 1745 m a.s.l. & 1920 m a.s.l. \\
\hline Slope degree & $23^{\circ}$ & $5^{\circ}$ & $40^{\circ}$ \\
\hline Exposure & North East & East & North \\
\hline Landform & Cave, Slope & Terrace & Gently slope bare rock \\
\hline Area & $175 \mathrm{~m}^{2}$ & $40.2 \mathrm{~m}^{2}$ & $84 \mathrm{~m}^{2}$ \\
\hline
\end{tabular}

Table 1: Locations and full description of the three enclosures of the Rosa arabica species in Saint Catherine area 
Citation: Moustafa AA, Zaghloul MS, Mansour SR, Alsharkawy DH, Alotaibi M (2017) Long Term Monitoring of Rosa arabica Populations as a Threatened Species in South Sinai, Egypt. J Biodivers Endanger Species 5: 197. doi: 10.4172/2332-2543.1000197

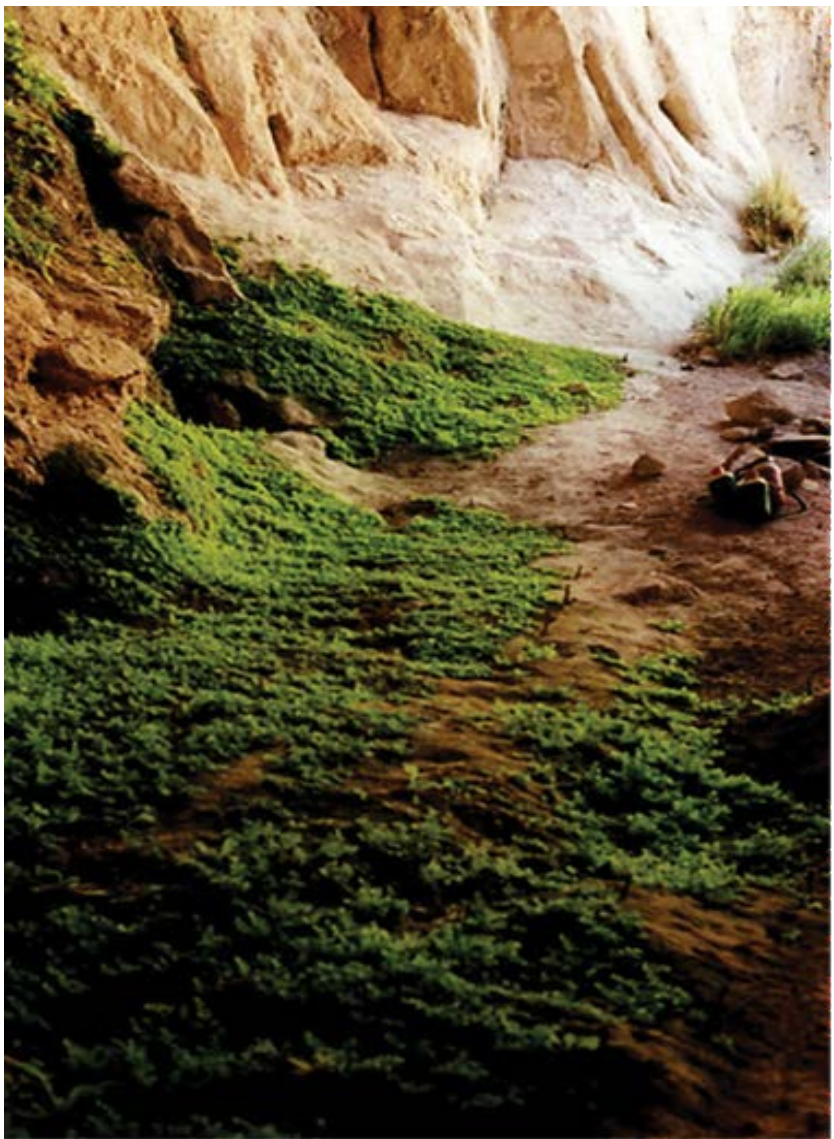

Figure 4: Side view of Kahf El-Ghoula showing the growth of Adiantum on the surface.

14 to 17 at the third readings, the three species were; Rosa arabica, Caesia parviflora, and Phlomis aurea. Also, a considerable increase in the number of the individuals of most species were recorded in the second and third readings, especially Nepeta septemcrenata which increased from 23 individuals in the second reading to 35 individuals in the third, Hypericum sinaicum (Figure 6) increased to un counted mat in the third reading, Mentha longifolia increased from one individual in the second reading to 19 individuals in the third one and Varthemia montana increased by 7 individuals

Site 3: This site covered the largest and the moistest part of the enclosure. It is distinguished into two landforms; namely, a vertical wall characterized by springs of water which provide the plant cover with moisture, and a horizontal floor. Primula boveana and Adiantum capillis-veneris dominate both parts. Four main plots were marked on the mate of mosses to monitor the changes in Primula boveana. The results revealed the positive effect of protection, which caused the increase in the dimensions, total number of individuals, and total coverage of both Primula and Adiantum on the mate of mosses covering the floor and the wall (Figure 7).

Enclosure No. 2: This enclosure is located at the garden of the Monastery in Wadi El-Arbae'en. The main results of this enclosure can be summarized as follows:

1. An observed increase in the cover percentage of Rosa Arabica from $27 \%$ to $34.96 \%$ at the last reading.

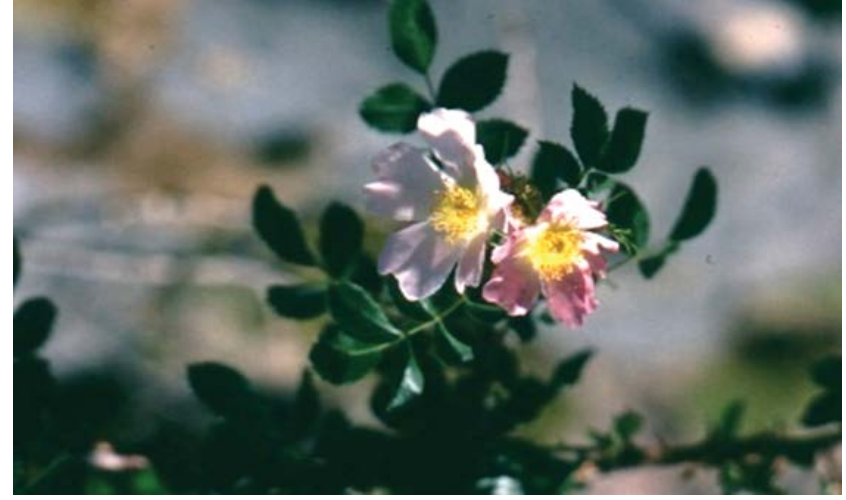

Figure 5: Rosa Arabica the target species in the present study.

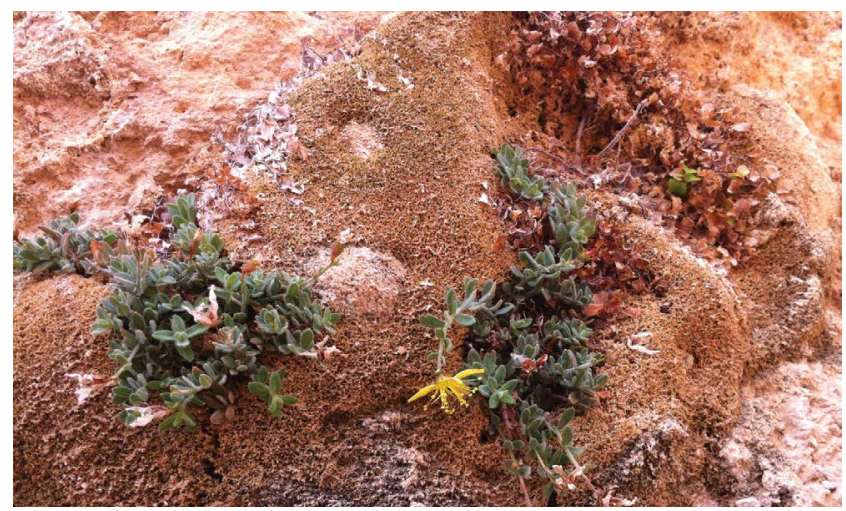

Figure 6: Hypericum sinaicum an endemic associated species in enclosure no. 1.

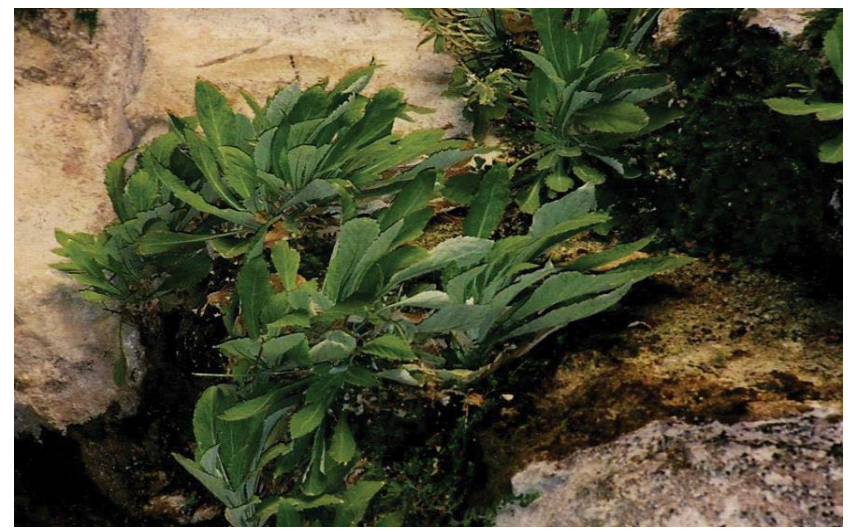

Figure 7: A very high growth rate of Primula boveana occurred at enclosures due to protection.

2. An observed increase in the number of individuals of Silene from one to 5 individuals and the total cover percentage from $0.056 \%$ to $2.26 \%$.

3. The number of associated species has increased such as Echinopus spinossimus and Artemisia herba-alba had also increased. On the contrary, fencing has apparently caused a decline in the number of seedlings of Achillea fragrantissima. 
Enclosure No. 3: This enclosure is located in Shaq Mussa. The main results of the second reading, after a period of protection, showed no big change on Rosa arabica, cover percentage increased about $1.6 \%$, but an increase in the number of Phlomis aurea growing inside the enclosure from 24 to 31 individuals. The number of associated species has increased from seven species in the first reading to fourteen species in the second reading. The most interesting species were Alkanna orientalis, Echinops spinosissimus, and Teucrium leucocladum which are not quite edible and palatable (Table 2).

Here we can say that conservation of the endemic target species Rosa arabica showed great fluctuation along the eighteen years of fencing in the enclosures since 1999. That in the first enclosure located in KahfElghola, the cover percentage of the $R$. arabica was about $13 \%$ with a positive effect of fencing in the second site of emergence of seven individuals during the second reading of the monitoring program. This percentage increased to $20 \%$ in 2004 . The second enclosure in Wadi El-Arbae'en, is very unique in its conservation potential as the cover percentage of the target species increased along the whole period of time from $35 \%$ in 1999 to $62.8 \%$ in 2014 [30], which is a support for the fencing effect on the protection of endemic species. The third enclosure in Shaq Mussa showed an increase in cover percentage, from $21.6 \%$ in 1999 to 23.9 in 2004.

Our results came in agreement with Al-Rowaily et al. [31] confirmed in their results on the importance of fencing for restoration of vegetation and preventing land degradation in arid regions. While, Cheng et al. [32] stated that there was an increase in plant diversity after long term fencing. They assumed that the accumulated amount of litter inside the enclosures may have negative effect on seedling recruitment of community, which may have led to species diversity loss once the plant density and aboveground biomass.

\begin{tabular}{|c|c|c|c|c|c|}
\hline \multirow{2}{*}{\multicolumn{2}{|c|}{ Enclosure No. }} & \multirow{3}{*}{$\begin{array}{l}\text { Parameters } \\
\text { Sp. Richness }\end{array}$} & \multicolumn{3}{|c|}{ Change (Readings) } \\
\hline & & & \multirow{2}{*}{$\begin{array}{c}\text { First } \\
1\end{array}$} & \multirow{2}{*}{$\begin{array}{c}\text { Second } \\
2\end{array}$} & \multirow{2}{*}{$\begin{array}{c}\text { Third } \\
2\end{array}$} \\
\hline \multirow{9}{*}{1} & \multirow{3}{*}{ Site (1) } & & & & \\
\hline & & \multirow{2}{*}{ Sp. diversity } & $0^{*}$ & $0.24^{*}$ & $0.24^{*}$ \\
\hline & & & $0^{* *}$ & $1.11^{* *}$ & $1.11^{* *}$ \\
\hline & \multirow{3}{*}{ Site (2) } & Sp. Richness & 14 & 16 & 17 \\
\hline & & \multirow{2}{*}{ Sp. diversity } & $0.96^{\star}$ & $0.95^{*}$ & $0.56^{*}$ \\
\hline & & & $8.06^{* *}$ & $8.13^{*+}$ & $7.05^{* *}$ \\
\hline & \multirow{3}{*}{ Site (3) } & Sp. Richness & 1 & - & 2 \\
\hline & & \multirow{2}{*}{ Sp. diversity } & $0^{*}$ & - & $0.33^{*}$ \\
\hline & & & $0^{* *}$ & - & $0.55^{* *}$ \\
\hline \multirow{3}{*}{2} & & Sp. richness & 9 & 10 & - \\
\hline & & \multirow{2}{*}{ Sp. diversity } & $0.7^{*}$ & $0.65^{\star}$ & - \\
\hline & & & $5.06^{* *}$ & $5.44^{* *}$ & - \\
\hline \multirow{3}{*}{3} & & Sp. richness & 7 & 16 & - \\
\hline & & \multirow{2}{*}{ Sp. diversity } & $0.61^{\star}$ & $0.51^{*}$ & - \\
\hline & & & $3.5^{* *}$ & $7.52^{* *}$ & - \\
\hline
\end{tabular}

'The species diversity according to Shanona index

"The species diversity according to Marglef index

Table 2: Species richness and species diversity expressed by Shannon's and Margalef's indices inside the three studied enclosures.

\section{Soil analysis}

The results of soil analysis were included estimation of moisture and organic content, $\mathrm{pH}$, electric conductivity, gravel percentage and soil texture. These results represent the principle situation of the soil before fencing (zero time). Moisture content and soil organic matter content were very high at enclosure no. one (Kahf El-Ghola), as it is area misted most of the year (Table 3). For $\mathrm{pH}$ values, the results showed that the lowest value was found also at enclosure no. one in Kahf ElGhola. Electric Conductivity (EC) values are very low generally, highest values found at enclosure no. one. Soil moisture, is the most limiting factor in the distribution of plant communities in South Sinai $[33,34]$, which strongly affect the abundance of species and distribution patterns among the whole area.

\section{Soil seed bank}

In the present study, of the sixty-one-species recorded in the standing above ground vegetation, only ten of the identified species were present in the soil seed bank. Some of the species recorded in the soil seed bank were not found in the standing vegetation. Thymus decussatus was not present in enclosure one, while enclosure two was the most one in species variation as the seed bank recorded six species Capparis sinaica, Mentha longifolia, Peganum harmala, Pulicaria crispa, Teucrium polium, Verbascum sinaiticum. Verbascum sinaiticum was the only species not among the standing vegetation in enclosure three. Although, our aim was to study the emergence of Rosa arabica among the soil seed bank samples, but the emergence of these important species was a good representation of the conservative potential of the soil seed banks. Aschero and Garcia [35] suggested that the positive effects of grazing on seedling emergence compensate for the negative effects on seed production and seedling and sapling survival and they recommended that management plans should consider that plant recruitment is closely related to land use, and that grazing exclusion does not necessarily guarantee system recovery in the long term (Table 4 ).

Generally, most of the species which are either recorded only in the standing vegetation and are absent from seed bank or abundant in the vegetation but rare in the seed bank are shrubs and long-lived perennials, these life forms in hot deserts have minimal dependence in soil seed

\begin{tabular}{|c|c|c|c|c|}
\hline \multirow{2}{*}{ Species list } & $\mathbf{1}$ & $\mathbf{2}$ & \multicolumn{2}{|c|}{$\mathbf{3}$} \\
\cline { 2 - 5 } & inside & inside & inside & outside \\
\hline Andrachne aspera & 0.00 & 0.00 & 0.00 & 0.00 \\
\hline Artemisia herba-alba & 0.00 & 26.63 & 23.97 & 10.65 \\
\hline Capparis sinaica & 0.00 & 15.98 & 0.00 & 0.00 \\
\hline Mentha longifolia & 0.00 & 2.66 & 0.00 & 0.00 \\
\hline Peganum harmala & 0.00 & 2.66 & 0.00 & 0.00 \\
\hline Pulicaria crispa & 0.00 & 13.32 & 0.00 & 0.00 \\
\hline Teucrium polium & 0.00 & 2.66 & 0.00 & 0.00 \\
\hline Thymus decussatus & 2.66 & 0.00 & 0.00 & 0.00 \\
\hline Verbascum sinaiticum & 0.00 & 31.96 & 31.96 & 15.98 \\
\hline Graminae & 7.99 & 37.29 & 26.63 & 21.31 \\
\hline Total & $\mathbf{1 0 . 6 5}$ & $\mathbf{1 3 3 . 1 6}$ & $\mathbf{8 2 . 5 6}$ & $\mathbf{4 7 . 9 4}$ \\
\hline
\end{tabular}

Table 4: The output data of seed bank experiment.

\begin{tabular}{|c|c|c|c|c|c|c|c|c|c|c|}
\hline \multirow{2}{*}{ Enclosure No. } & \multirow{2}{*}{$\mathrm{pH}$} & \multirow{2}{*}{ EC mhos/c m } & \multirow{2}{*}{$\begin{array}{l}\text { Moisture } \\
\text { content } \%\end{array}$} & \multirow{2}{*}{$\begin{array}{l}\text { Organic } \\
\text { matter \% }\end{array}$} & \multirow{2}{*}{ Gravel\% } & \multicolumn{5}{|c|}{ Fine Soil Texture } \\
\hline & & & & & & Total Sand\% & Coarse Sand\% & Fine Sand\% & Silt $\%$ & Clay $\%$ \\
\hline 1 & 7.75 & 6.99 & 2.5 & 12.52 & 68.36 & 79.67 & 0.00 & 79.67 & 13.64 & 6.69 \\
\hline 2 & 8.11 & 0.34 & 0.6 & 7.83 & 36.36 & 87.75 & 50.31 & 37.43 & 9.30 & 2.95 \\
\hline 3 & 7.95 & 0.44 & 0.55 & 7.18 & 60.50 & 84.32 & 31.14 & 53.18 & 10.49 & 5.19 \\
\hline
\end{tabular}

Table 3: Soil characteristics of the monitored enclosure of St. Catherine protectorate. 
Citation: Moustafa AA, Zaghloul MS, Mansour SR, Alsharkawy DH, Alotaibi M (2017) Long Term Monitoring of Rosa arabica Populations as a Threatened Species in South Sinai, Egypt. J Biodivers Endanger Species 5: 197. doi: 10.4172/2332-2543.1000197

bank for regeneration and protection against climatic uncertainty $[36,37]$. Their strategy is to produce few seeds almost every year, most of which do not persist in the seed bank. To the extent that the onset of good conditions is predictable (i.e., the warming of spring or the onset of a rainy season), cues such as temperature, photoperiod, moisture, or seed age may be used to trigger germination [38]. Philippi [38] also stated that desert annuals species, in addition to having mechanisms that allow seeds to germinate only under appropriate conditions, also must have some trait that allows them to persist in the face of environmental unpredictability and may have traits that specifically exploit it. Seed dormancy for more than one year is thought to be a bet-hedging adaptation to environmental uncertainty in desert annuals.

\section{Conclusion}

Rosa arabica is an endemic species of the family Rosaceae, growing in mount Catherine in the South Sinai in Egypt, it is threatened and may be subjected to extinction [39]. Evaluation of the status of the protected populations shows that there is no real conservation plan for that species and it necessarily needs more protection, restoration, and reintroduction. Grazing represents a great disturbance for natural vegetation and endangering some endemic species of extinction. Elimination of grazing through fencing resulted in higher percentages of total plant cover, higher diversity index and species richness, and higher growth rates of endemic species. Soil seed bank may represent a potential resource in restoration and establishing some of endemic species and native vegetation as well, although, endemic species show variation in germination behavior in soil seed bank, but it still a good tool for restoration of the vegetation. From the present study, the following recommendations should be considered: Measurements for protecting and managing of the endemic species in Saint Katherine Protectorate should be preceded by intensive and extensive (long term) autecological studies on all the recorded endemic species in the area. Grazing, cutting and all the other human activities in Saint Catherine area should be managed. Restoration of the endangered endemic species by soil seed bank and transplanting should be studied. Applying of biosphere protected area is the most suitable protecting strategy in Saint Catherine protectorate. Ecological public awareness should be raised and the environmental sound traditions should be developed and considered to make a culturally-compatible management.

\section{References}

1. Moustafa AA, Klopatek JM (1995) Vegetation and landforms of the Saint Catherine area, southern Sinai, Egypt. J Arid Environ 30: 385-395.

2. Ramadan AA (1988) Ecological studies in Wadi Feiran, its tributaries and the adjacent mountains. PhD Thesis, Faculty of Science, Suez Canal University, Egypt.

3. Kamh M, Horst W J, Amer F, Mostafa H, Maier P (1999) Mobilisation of soil and fertilizer phosphate by cover crops. Plant Soil 211: 19-27.

4. Abd El-Wahab RH (1995) Reproduction ecology of wild trees and shrubs in Southern Sinai, Egypt. MSc thesis, Botany Department, Faculty of Science, Suez Canal University, Ismailia, Egypt.

5. Abd El-Wahab RH, Zaghloul MS, Moustafa AA (2004) Conservation of medicinal plants in St. Catherine Protectorate, South Sinai, Egypt. I. Evaluation of ecological status and human impact. Proc I Inter Conf on Strategy of Egyptian Herbaria, Giza, Egypt, pp: 231-251.

6. IUCN (1978) Classification and Use of Protected Natural and Cultural Areas IUCN Occasional Paper No. 4, Morges: IUCN.

7. Duke JA, Bogenschutz-Godwin MJ, duCellier J, Kessler Duke PA (1985) Handbook of Medicinal Herbs (2nd Edn). CRC Press, Boca Raton, p: 633.

8. Madaus G (1979) Lehrbuch der biologischen Heilmittel. Georg Olms Verlag, Hildesheim-New York, USA.
9. Saxena M, Shakya AK, Sharma N, Shrivastava S, Shukla S (2012) Therapeutic Efficacy of Rosa Damascena Mill. On Acetaminophen-Induced Oxidative Stress in Albino Rats. J Environ Pathol Toxicol Oncol 31: 193-201.

10. Mahboubi M (2016) Rosa damascene as holy ancient herb with novel applications. J Tradit Complement Med 6: 10-16

11. Täckholm V (1974) Students' flora of Egypt (2 ${ }^{\text {nd }}$ Edn.), Beirut: Cairo University

12. Boulos L (1995) Flora of Egypt - checklist. Al-Hadara publishing, Cairo, Egypt

13. Boulos L (2008) Flora and Vegetation of the Deserts of Egypt. FI Medit 18: 341-359.

14. Souleman AMA, El Mousallamy AMD (2000) Chemical investigation of the constitutive phenolics of Rosa arabica. J Nat Prod 6: 82.

15. Said R (1962) The Geology of Egypt. Elsever Publishing Company. Amsterdam

16. Ayyad MA, Fakhry AM, Moustafa AA (2000) Plant biodiversity in Saint Catherine area of the Sinai Peninsula, Egypt. Biodiversity and conservation 9: 265-281.

17. Alsharkawy DH (2014) Seed Ecology of Threatened Medicinal species Growing in Saint Catherine area. MSc Thesis, Botany Department, Faculty of Science, Suez Canal University, Ismailia, Egypt.

18. Braun-Blanquet $J$ (1932) Plant sociology: the study of plant communities. McGraw-Hill, New York, NY, USA.

19. Misra R, Puri GS (1954) Indian Manual of Plant Ecology, English Book Depot, Dehradun.

20. Dubenmire R (1968) Ecology of fire in grasslands. Adv Ecol Res 5: 209-266.

21. Hausenbuiller RL (1985) Soil science and principles practices ( $3^{\text {rd }}$ Edn.), Wm C BrownCompany Publishers.

22. Gee GW, Bauder JW (1986) Particle-size Analysis. In: Klute A (editor) Methods of soil analysis. Part I, Physical and Mineralogical Methods. 2nd edition. Agronomy 9. American Society of Agronomy, Madison, Wisconsin, USA.

23. Sparks DL, Page AL, Helmke PA, Loeppert HR, Soltanpour PN, et al. (1996) Methods of soil analysis, part 3: chemical methods. American Society of Agronomy, Madison, Wisconsin, USA.

24. Allen SE, Grimshaw HM, Parkinson JA, Quarmby E, Roberts, JD (1976) Chemical analysis. In: Methods in plant ecology (editor) Chapman SB, Blackwell Scientific, Oxford pp: 411-460.

25. Wilde S A, Voigt GK, Lyer JG (1972) Soil and Plant analysis for tree culture. Edited by Gordon chesters. Applied Science publishers.

26. Zaghloul MS (1997) Ecological studies on some endemic plant species in South Sinai, Egypt. MSc Thesis. Department of Botany, Faculty of Science, Suez Canal University, Egypt.

27. Habrova H, Pavlis J (2015) Dynamic response of woody vegetation on fencing protection in semi-arid areas; Case study: Pilot exclosure on the Firmihin Plateau, Socotra Island. Saudi J Biol Sci 24: 338-346.

28. Aerts R, Nyssen J, Haile M (2009) On the difference between "exclosures" and "enclosures" in ecology and the environment. J Arid Environ 73: 762-763.

29. Benaradj A, Boucherit H, Mederbal K, Benabdeli K, Baghdadi D (2011) Effect The Exclosure on Plant Diversity of The Hammada Scoparia Steppe in the Naama Steppe Courses (Algeria). J Mater Environ Sci 2: 564-571.

30. Omar KA (2014) Evaluating the Effectiveness of In-situ Conservation on Some Endemic Plant Species in South Sinai, Egypt. Am J of Life Sci 2: 164-175.

31. Al-Rowaily S, Assaeed A, El-Bana M, Hegazy A, Al-Bakre D, et al. (2015) Effects of open grazing and livestock exclusion on floristic composition and diversity in natural ecosystem of Western Saudi Arabia. Saudi J Biol Sci 22 430-437.

32. Cheng JM, Jing GH, Wei L, Jing ZB (2016) Long-term grazing exclusion effects on vegetation characteristics, soil properties and bacterial communities in the semi-arid grasslands of China. Ecological Engineering 97: 170-178.

33. Moustafa AA, Zayed AM (1996) Effect of environmental factors on the flora of alluvial fans in southern Sinai. J Arid Environ32: 431-443

34. Moustafa A, Zaghloul MS (1996) Environment and vegetation in the montane Saint Catherine area, South Sinai, Egypt. J Arid Environ 34: 331-349. 
Citation: Moustafa AA, Zaghloul MS, Mansour SR, Alsharkawy DH, Alotaibi M (2017) Long Term Monitoring of Rosa arabica Populations as a Threatened Species in South Sinai, Egypt. J Biodivers Endanger Species 5: 197. doi: 10.4172/2332-2543.1000197

Page 8 of 8

35. Aschero V, Garcia D (2012) The fencing paradigmin woodland conservation: consequences for recruitment of a semi-arid tree. Appl Veget Sci 15: 307-317.

36. Hegazy AK, Hammouda O, Lovett-Dous J, Gomaa NH (2009) Variations of the germinable soil seed bank along the altitudinal gradientin the northwestern Red Sea region. Acta Ecologica Sinica 29: 20-29.

37. Zaghloul M S (2008) Diversity in soil seed bank of Sinai and implications for conservation and restoration. African Journal of Environmental Science and Technology 2: 172-184.

38. Philippi T (1993) Bet-hedging germination of desert annuals: beyond the first year. Am Nat 142: 474-487.

39. Hepper FN, Friis I (1994) The Plants of Pehr Forsskal's "Flora AgeyptiacoArabica". Kew: Kew Publishing. 